\title{
Synthesis of (+)-Quebrachamine
}

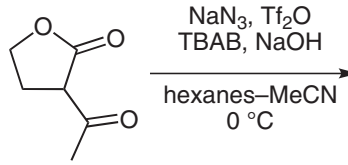

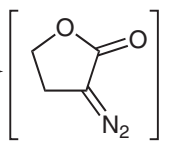

$\mathrm{N}_{2}$

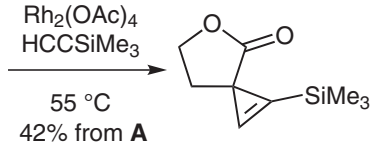

B
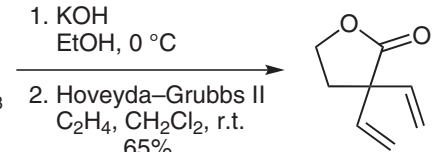

$65 \%$

$65 \%$
Key words

quebrachamine

enantioselective

ring-closing

metathesis

chiral molybdenum catalysts<smiles>C=CCN(CC=C)CCCC1=C(CC)CCC1(C=C)C=C</smiles>

1. allyl chloroformate THF, $-78^{\circ} \mathrm{C}$ then $\mathrm{NaCNBH}_{3}$ THF, $-78^{\circ} \mathrm{C}$ to $0^{\circ} \mathrm{C}$ 2. $\mathrm{Pd}\left(\mathrm{PPh}_{3}\right)_{4}, \mathrm{CH}_{2} \mathrm{Cl}_{2}$, r.t. $82 \%$<smiles>C=CC1(C=C)CC2c3[nH]c4ccccc4c3CCN2C1</smiles>
$\mathrm{PhMe}, 80^{\circ} \mathrm{C}$

\section{2. $\mathrm{LiAlH}_{4}$, THF} $0-65{ }^{\circ} \mathrm{C}$ 1. $\mathrm{HNMe}(\mathrm{OMe}) \cdot \mathrm{HCl}$ - $\mathrm{PrMgCl}, \mathrm{pH} 7$ buffer THF, $0^{\circ} \mathrm{C}$ to r.t. 2. Swern oxidation
Significance: Quebrachamine is an Aspidosperma alkaloid that is an adrenergic blocker. This synthesis is noteworthy for the highly enantioselective ring-closing cross-metathesis $(\mathbf{G} \rightarrow \mathbf{I})$ using a chiral molybdenum catalyst which is stereogenic at the metal center.
Comment: The catalyst $\mathbf{H}$ was made by a diastereoselective desymmetrization $(\mathrm{dr}=7: 1)$ of a Mo bispyrrolide precursor with one equivalent of monosilyl-protected octahydrobinaphthol in benzene at room temperature. No improvement on the impressive enantiomeric ratio was seen when diastereoisomerically pure $\mathbf{H}$ was used. 